IZA DP No. 6885

Why Do Women Leave Science and Engineering?

Jennifer Hunt

September 2012

Forschungsinstitut zur Zukunft der Arbeit Institute for the Study of Labor 


\title{
Why Do Women Leave Science and Engineering?
}

\author{
Jennifer Hunt \\ Rutgers University, \\ NBER and IZA
}

\section{Discussion Paper No. 6885 \\ September 2012}

\author{
IZA \\ P.O. Box 7240 \\ 53072 Bonn \\ Germany \\ Phone: +49-228-3894-0 \\ Fax: +49-228-3894-180 \\ E-mail: iza@iza.org
}

Any opinions expressed here are those of the author(s) and not those of IZA. Research published in this series may include views on policy, but the institute itself takes no institutional policy positions. The IZA research network is committed to the IZA Guiding Principles of Research Integrity.

The Institute for the Study of Labor (IZA) in Bonn is a local and virtual international research center and a place of communication between science, politics and business. IZA is an independent nonprofit organization supported by Deutsche Post Foundation. The center is associated with the University of Bonn and offers a stimulating research environment through its international network, workshops and conferences, data service, project support, research visits and doctoral program. IZA engages in (i) original and internationally competitive research in all fields of labor economics, (ii) development of policy concepts, and (iii) dissemination of research results and concepts to the interested public.

IZA Discussion Papers often represent preliminary work and are circulated to encourage discussion. Citation of such a paper should account for its provisional character. A revised version may be available directly from the author. 
IZA Discussion Paper No. 6885

September 2012

\section{ABSTRACT}

\section{Why Do Women Leave Science and Engineering?*}

I use the 1993 and 2003 National Surveys of College Graduates to examine the higher exit rate of women compared to men from science and engineering relative to other fields. I find that the higher relative exit rate is driven by engineering rather than science, and show that $60 \%$ of the gap can be explained by the relatively greater exit rate from engineering of women dissatisfied with pay and promotion opportunities. I find that family-related constraints and dissatisfaction with working conditions are only secondary factors. The relative exit rate by gender from engineering does not differ from that of other fields once women's relatively high exit rates from male fields generally are taken into account.

JEL Classification: J16, J44

Keywords: science and engineering workforce, gender

Corresponding author:

Jennifer Hunt

Department of Economics

Rutgers University

75 Hamilton Street

New Jersey Hall

New Brunswick, N.J. 08901-1248

USA

E-mail: jennifer.hunt@rutgers.edu

\footnotetext{
* I thank Leah Brooks, Daniel Parent and participants in seminars at Bocconi University, the CLSRN annual conference, McGill University, the NBER, UBC and the University of Milan for comments. I am grateful to David Munroe and Marjolaine Gauthier-Loiselle for research assistance and to the Social Science and Humanities Research Council of Canada for financial support. This paper was written while I was a visiting professor at the University of British Columbia. I am also affiliated with the CEPR (London), IZA (Bonn), and DIW (Berlin).
} 
An education system and labor market which combine to match workers to the appropriate qualifications and jobs contribute to the static efficiency of an economy. This matching may be especially important for combinations of qualifications and jobs that lead to technological innovation, and hence economic growth. The low share of women in science and engineering therefore suggests the possibility of both static and dynamic inefficiency, particularly given women's very low share of patents (7.5\% in 2003; Hunt 2011). Women's underrepresentation in engineering may be more significant for innovation and growth than their underrepresentation in science: Hunt (2011) finds that most of the gender patenting gap is among holders of science and engineering degrees and that this group's gap is due in large part to women's underrepresentation in engineering and overrepresentation in life sciences.

Women's representation in science and engineering is determined by both entry and exit. Women's low entry to science and engineering has been examined in the context of choice of field of study ${ }^{1}$, while Preston $(1994,2004,2006)$ has documented that women leave science and engineering at a higher rate than men. Given that pre-labor market obstacles are likely to cause women entering science and engineering to be more positively selected for interest and aptitude than their male counterparts, women's higher exit rates hint at labor market inefficiency. Certain practices in science and engineering firms may prevent women from reaching their full potential, or there may be outright discrimination against women in such firms. The existence of such practices or discrimination could in turn discourage forward-looking women from entering science and engineering. In this paper, I introduce a new way of considering female exits from science and engineering and their link to women's underrepresentation in those fields.

Preston $(1994,2004,2006)$ has demonstrated that while female scientists and engineers are more likely than their male counterparts to stop working, they are also more likely to move to a job outside science and engineering. The considerable literature on women leaving science and engineering highlights the difficulty of balancing long work hours and

\footnotetext{
${ }^{1}$ Some recent examples are Antecol and Cobb-Clark (2010), Stinebrickner and Stinebrickner (2011), Zafar (2008).
} 
family in science and engineering, the isolation of being a minority and the associated lack of mentoring and networks, the risk-taking environment, the "hostile macho culture" and discrimination. ${ }^{2}$ However, with the exception of Morgan (2000), the research of which I am aware uses samples of current or former scientists and engineers only, without any comparison with other skilled occupations. ${ }^{3}$ It is possible that educated women in general simply churn more than men in seach of the optimal job, and that science and engineering cannot be distinguished from other fields in terms of the gender gap in exit rates. If this is the case, it may not be fruitful to study exit rates to understand women's underrepresentation in science and engineering.

If it is established that science and engineering stand out from other fields in terms of excess female exits, further comparisons with other fields are important in order to understand the reasons for the excess exits and the link with women's underrepresentation in science and engineering. A common explanation in the literature for women quitting science and engineering is that work hours are long, and hence difficult to combine with family. Yet jobs in many other fields have long hours, and educated women may leave all fields at a higher rate than men as they search for a job with optimal work hours. If so, women's underrepresentation in engineering is unlikely to be due to long work hours.

In this paper, I use the 1993 and 2003 National Surveys of College Graduates to investigate whether and why women whose highest degree is in science or engineering cease doing science and engineering-related work at higher rates than similarly trained men. Unlike earlier authors, I use non-science and engineering fields as a control group, and also contrast science and engineering. The results shed light on which interventions if any are most likely to increase female representation in science and engineering.

I demonstrate that the exit rate for women compared to men is indeed higher from engineering than from other fields, due to excess exits to jobs in another field, but that

2 Fouad and Singh (2011), Hall (2007), Hewlett et al. (2008), Preston (1994, 2004, 2006), Sonnert and Holton (1995), Stephan and Levin (2005); see also Rosser and Taylor (2009) and Xie and Shauman (2003). Frehill (2007, 2008, 2009) deemphasizes family and instead highlights changes in career interests.

3 My analysis goes beyond that of Morgan (2000), who uses the 1993 NSCG to compare exits from full-time employment of women from different fields. 
there is no similar pattern for science. Furthermore, I show that the problems are not those emphasized by the previous literature. Rather, I find that the most important driver of excess female exits from engineering is dissatisfaction over pay and promotion opportunities, a factor explaining about $60 \%$ of the differential gender gap in exit rates. Concerns about pay and promotion have gone unnoticed by the literature studying only science and engineering fields, because women are slightly less likely to leave engineering for this reason than men; however, women are much less likely than men to leave nonscience and engineering fields for this reason. Family-related constraints are not a factor: while many more women than men cite family issues as the reason for leaving engineering, the gender gap is as large in non-science and engineering fields. I find that working conditions, the unavailability of a job in the field, changes in professional interests and job location play statistically significant but minor roles. I do find slight excess exits of women from science for family-related reasons; these are offset by relatively lower female exits for all other reasons.

In seeking explanations for why women engineers may be particularly disgruntled about pay and promotion, it is helpful to know that their relatively high exit rates, both in total and for pay and promotion reasons, are no higher than would be expected given the high share of engineers that is male: compared to men, women have relatively higher total and pay and promotion-motivated exit rates from more male fields of study. Excess female exits from a field are not influenced by the field's working hours, wages, or share of workers in management, though these are all positively correlated with the male share. The implication is that a lack of mentoring and networks, or discrimination by managers and co-workers are the more promising of the existing explanations for excess female exits, and that explanations hinging on the precise nature of engineering work should be discarded. The slight excess female exits from science for family-related reasons are not accounted for by the share of trained scientists that is male. 


\section{Data and descriptive statistics}

I use the 1993 and 2003 waves of the National Survey of College Graduates, data collected under the auspices of the National Science Foundation. The surveys are a stratified random sample of respondents to the 1990 and 2000 census long forms who reported having a bachelor's degree or higher. I define someone as having left a field if they state that their current work is not related to the field of study of their highest degree. The surveys ask: "Thinking about the relationship between your work and your education, to what extent was your work on your principal job held during the week of [...] related to your HIGHEST degree field? Was it... closely related/somewhat related/not related?" If the respondent answered "not related", he or she was asked "Did these factors influence your decision to work in an area outside of your HIGHEST degree field?" and given a list of possible factors to check: family-related reasons; working conditions; pay, promotion opportunities; job in highest degree field not available; change in career or professional interests; job location; other reason. He or she was then asked "Which factor in [the list] represents your MOST important reason for working in an area outside of your HIGHEST degree field?".

In addition to conventional variables on salary and demographics, I also take advantage of the question asked of all workers in 2003: "When thinking about a job, how important is each of the following factors to you . . .", a question followed by a list of job attributes: salary, benefits, job security, job location, opportunities for advancement, intellectual challenge, level of responsibility, degree of independence, contribution to society. Workers must indicate whether each factor is very important, somewhat important, somewhat unimportant or not important at all.

The advantage of the data is that they allow identification of who has left their field and why, for all fields. The disadvantage is that the date of the exit is not known, which precludes hazard rate analysis of the type carried out by Preston (1994). Preston (1994, 2004, 2006) uses the 1980s and 1990s longitudinal files associated with the NSCG (in addition to her own survey), but these cover only those working in science and engineering 
occupations. The cross-sectional nature of my data also imposes the use of field of study of highest degree to determine initial field. Unlike in occupation-based samples, exits thus include exits after the completion of studies and before the first job. I discuss the relation between the two types of exit in the Data Appendix.

I use two samples in my analysis, from all of which I exclude respondents 65 or older. The main sample used to analyze working in the field of study consists of all workers, except those working part-time because they are students, and 197,686 observations. The second sample, used to analyze the probability of working, consists of all respondents except those who say they are working part-time or not working because they are students, yielding a sample of 222,853 observations. The Data Appendix describes the samples in more detail.

In the top panel of Table 1, I show that about $20 \%$ of both men and women report that the work in their current job is unrelated to their field of study of their highest degree. Men and women differ in their distribution between the other two categories, with more women than men saying their work is closely related to their field of study. For those reporting that their work is unrelated to their field of study, I show in the middle panel the distribution of the main reason for this. The main gender differences are the much higher share of women who are working in a different field for family-related reasons ( $4.1 \%$ of women compared to only $1.2 \%$ of men), and the smaller share of women who are working in a different field due to pay and promotion opportunities $(4.1 \%$ of women compared to $6.5 \%$ of men). Women are somewhat more likely work in a different field due to dissatisfaction with working conditions. The bottom panel shows a similar pattern for the shares of workers citing the various factors behind working in a different field as either the main reason or a secondary reason.

In my data, $9.7 \%$ of men and $6.0 \%$ of women have a highest degree in science, and $14.2 \%$ of men and only $2.9 \%$ of women have a highest degree in engineering. ${ }^{4}$ In Figure 1 ,

\footnotetext{
${ }^{4}$ By "science" I mean natural sciences, excluding social sciences and health fields. I include computer science with engineering and mathematics with science. The statistics are weighted with the survey weights.
} 
I show the male and female exit rates from science, engineering and non-science and engineering by years since highest degree (which I aggregate in order to smooth the graph). The divergence between men and women appears to occur earlier in engineering than in other fields (alternatively, changes across cohorts have occurred more recently). More detail on field of study by gender and on exit rates from fields of study is given in Appendix Table 1, while Appendix Tables 2 and 3 show the means of the other covariates used in the regressions below.

\section{Method}

I begin by establishing whether women do indeed disproportionately leave science and engineering for non-employment or an unrelated job. The approach is a difference-indifferences analysis: to compare the gender gap for science and engineering with the gender gap for other fields of study. I then investigate whether any excess exits I find can be explained with worker characteristics. I allow separate difference-in-differences for science and engineering, estimating a basic specification using linear probability regressions, weighted with survey weights, for the pooled years 1993 and 2003:

$$
Y_{i t}=\beta_{0}+\beta_{1} S_{i t}+\beta_{2} E_{i t}+\beta_{3} F_{i t}+\beta_{4} S_{i t} \times F_{i t}+\beta_{5} E_{i t} \times F_{i t}+\beta_{6} X_{i t}+\beta_{7} F_{i t} \times \gamma_{t}+\gamma_{t}+\epsilon_{i t},
$$

where $i$ indexes individuals and $t$ the year, $S$ is a dummy for the field of study of highest degree being in science, $E$ the equivalent for engineering, and $F$ is a dummy for female. Excess female exits from science and engineering would be reflected in $\beta_{4}$ and $\beta_{5}$. In a more general specification, I replace the dummies for science and engineering with a set of 35 field of study dummies. I calculate robust standard errors. I pool 1993 and 2003 because the effects of interest do not in general differ statistically significantly across the years, though I allow the coefficient on the female dummy to vary by year.

The first outcome $Y$ of interest is a dummy for being employed, an outcome I study with the sample of all respondents. The second is a dummy for the current job being unrelated to the field of study of the highest degree, an outcome I study with the sample 
of workers. Excess female exits would be reflected in positive $\beta_{4}$ and $\beta_{5}$ for holding an unrelated job, and negative $\beta_{4}$ and $\beta_{5}$ for being employed. With the sample of workers, I also examine the probability of the current job being unrelated to the field of study for a specific reason. For example, I estimate a linear probability model for the probability of a worker having left his or her field and cited family as the main reason, and a second for the probability of a worker having left his or her field and cited family as either the main reason or a secondary reason. Only one of the seven possible reasons can be given as the main reason, but for ease of interpretation I do not use a multinomial or nested logit to examine the choice.

The covariates $X$ comprise dummies for a master's degree (including MBA), doctoral degree or professional degree, five dummies for years since highest degree, six dummies for age, dummies for black, Hispanic and Asian, and dummies for foreign born. If I restrict the sample to 2003, I can also control for three dummies each for the importance the respondent attaches to the nine job attributes. In this way, I can control for initial selection into different fields (though ideally the job preferences would be measured before the respondent began working) - for example, engineering may attract women who care more about pay and promotion than other women.

I do not control for fertility (or marriage) in these regressions, since the fertility choice is made jointly with the decision of whether to remain in the field of study (or to remain employed). However, the correlation between fertility and remaining in the field of study may be informative, so I examine it in additional regressions. I do not know the timing of leaving the field of study, so I would ideally use information on lifetime fertility to date. However, I know only the number and ages of children of the respondent living in the household at the time of the survey, so I proxy lifetime fertility with a dummy $C_{i t}$ for whether any child of the respondent (of any age) is living in the household. I explore gender and field differentials in the relation between fertility and how closely related the respondent's job is to his or her field of study, by adding $C_{i t}, C_{i t} \times F_{i t}, C_{i t} \times S_{i t}, C_{i t} \times E_{i t}$, $C_{i t} \times S_{i t} \times F_{i t}$ and $C_{i t} \times E_{i t} \times F_{i t}$ to equation (1). A positive coefficient on the triple interactions in a regression for working in an unrelated job would suggest that women 
have more difficulty combining work and children in science and engineering than in other fields, relative to men.

In equation (1), science and engineering are being compared to a set of fields of study as disparate as business, teaching and technology (i.e. technical training below the level of engineering). While science and engineering may seem naturally distinct, due to their mathematical nature and use of equipment and laboratories, it is possible that what in fact distinguishes them is their high share of male workers. Female exits may increase relative to male exits as the share of male workers increases, and any apparent specificities of science and engineering may simply reflect this.

To test this, I allow for excess female exits from male-dominated fields by replacing the field dummies in equation (1) with dummies for science and engineering, $m_{j}$ and $m_{j} \times F_{i j t}$, where $m_{j}$ is the share of men in field of study $j$. For this purpose, I use the most detailed field of study categories (143 categories). If $\beta_{4}$ and $\beta_{5}$ were statistically significant and change little with the addition of these covariates, the share of males in a field of study is not relevant for gender differences between science and engineering and other fields. If $\beta_{4}$ and $\beta_{5}$ become statistically insignificant, science and engineering exit rates merely reflect their male-dominated work force. I cluster the standard errors by detailed field of study.

\section{Results}

\subsection{Are there excess female exits from science and engineering?}

I begin by establishing whether science and engineering do have excess female exits compared to other fields employing workers with a college education or more. In Table 2, I consider exits to non-employment, using the sample of all respondents. The first three rows indicate, as expected, that for those trained in science, engineering and other fields, the share of women who are employed is lower than the share of men who are employed. What is potentially interesting is how the gender gap differs across the fields. The fourth row shows that if science is compared with other fields, there is no statistically significant 
difference in the gender employment gap. The fifth row shows that women as trained engineers have a statistically significant 2.5 percentage point employment advantage relative to other fields: the opposite of what would be expected if women were driven from employment for engineering-specific reasons. The unreported results for the probability of working part-time rather than full-time are very similar: the gender gap in science is the same as in other fields, while the gender gap in engineering relative to other fields indicates that female engineers are relatively unlikely to work part-time (the differencein-differences is 4.1 percentage points).

Next, I look for evidence of excess female exits from science and engineering to employment in other fields. In Table 3, I consider the share of workers whose job is not related to their field of study of highest degree. $23-24 \%$ of both men and women who studied science have an unrelated job, larger shares than the $21 \%$ of both men and women who studied something other than science and engineering who are working in a job not related to their field of study. The difference in the gender gap is not large: a statistically insignificant 1.1 percentage points excess exit rate of women from science. This is not necessarily at odds with the existing literature, which typically does not separate science and engineering.

The table also shows that the exit rate from engineering is very low for men: only $9.8 \%$ of men trained as engineers are doing unrelated work. While the exit rate is also low for women, at $12.9 \%$ it is considerably higher than for men. The comparison of the gender gap in engineering with non-science and engineering fields therefore shows a statistically significant 3.2 percentage point excess exit rate of women from engineering. This excess exit rate is small compared to the female shortfall in entry to engineering, but its elimination could encourage female inflows.

\subsection{Why do women leave science and engineering?}

To probe further the relatively low exits to non-employment of female engineers in Table 2, I estimate equation (1) with employment as the dependent variable. The first column of 
Table 4 presents a specification almost equivalent to the simple difference-in-differences in the Table 2, except that a year dummy and its interaction with female are also controlled for. The coefficients on the two interaction terms represent the difference-in-differences effects. In column 2, I replace the dummies for science and engineering with 35 field of study dummies, and in column 3 I add the remaining covariates. In column 3 , the gender gaps between science and engineering and other fields are small and insignificant: the high employment rate of women trained as engineers in column 1 is explained by field of study (column 2) and age and years since highest degree. Restricting the sample to 2003 or to respondents who received their highest degree in 1980 or later also yields small and insignificant coefficients on the interaction terms (see Hunt 2010).

It is possible that the lack of differential employment patterns by gender and field masks informative differences in the reasons for non-employment, but unreported results indicate this is not the case: I repeat the regressions seven times, each time using as the dependent variable the probability of not working for one of seven possible reasons respondents can give (see Hunt 2010). I have also estimated the regressions for workers, with full-time work as the outcome, to see if science and engineering women are pushed to work part-time, thereby exploiting their science and engineering human capital only incompletely. The unreported results indicate no difference in the gender gap between science and other fields, and a wrongly-signed positive difference-in-differences effect of 2.5 percentage points for engineering, in the specification with the full covariates. I conclude that excess female exits from science and engineering are present only in exits to another job, and therefore turn in Table 5 to explaining the differences in how closely related a worker's job is to his or her field of study of highest degree.

The specification of Table 5 column 1 reports the difference-in-difference effects for science and engineering from a regression that is close to equivalent to the analysis of Table 3, and hence yields very similar results. In column 2, I allow the probability of having work unrelated to the field of study to vary by 36 fields of study. The estimated excess exits remain statistically insignificant for science, but grow for engineering from 3.3 to 5.7 percentage points. Accounting for how men and women are distributed among fields 
within science, engineering and non-science and engineering thus reinforces the puzzle of the excess exits.

The unchanged excess exits from engineering in column 3 indicate that excess exits are not explained by a distinctive pattern in education, experience or demographics. The excess female exit rate from science remains statistically insignificant and is very small. This could reflect opposing effects of unmeasured factors: more difficult working conditions in science for women than men and greater science interest and aptitude of women than men in science. In Hunt (2010), I show the results are robust to using 2003 only, and to accounting for the importance workers attribute to various job characteristics, including salary and opportunities for advancement.

I pursue the analysis of the causes of women leaving science and engineering by using the reasons given by respondents whose job is not related to their field of study. In Panel A of Table 6, I consider the probability of leaving the field of study for each of the possible main reasons, after controlling for the full set of covariates (as in Table 5, column 3). Column 1 shows that there are statistically significant excess female exits from science for family-related reasons, of 1.3 percentage points, but no such excess exits for engineering. Column 2 shows that pay and promotion opportunities play an important role in excess female exits from engineering: the coefficient on the engineering interaction term indicates a 3.6 percentage point effect, accounting for $62 \%$ of the total conditional excess exits of 5.8 percentage points (in Table 5, column 3). These results are robust to using 2003 only, and to controlling for individuals' job preferences (results not reported), showing they do not arise because women who care particularly about pay and promotion disproportionately choose to study engineering. There are no excess exits of women from science for pay and promotion reasons.

The role of pay and promotion has been overlooked in the previous literature, because the exit rate from engineering for pay and promotion reasons is similar for men and women (the unreported single difference is an insignificant 0.3 percentage points). However, in non-science and engineering fields, women are 3.1 percentage points less likely than men to leave for pay and promotion reasons. 
Columns $3-7$ suggest that working conditions, the unavailability of a job in the field, changes in career interests and job location play no role in excess female exits from either science or engineering, though "other" reasons play a small statistically significant role for engineering. I conclude from Panel A of Table 6 that the most important reason for women leaving engineering at higher rates than men is pay and promotion opportunities. Women trained in science are affected to a smaller extent by family-related reasons, which are offset by all the other reasons collectively, though none is individually statistically significant.

In Panel B of Table 6, I search for more minor causes, by estimating the probability of a reason being mentioned at all, whether it is the most important reason or not. The difference-in-differences effect for engineering is positive and statistically significant for every reason except family-related reasons. This points to there being many reasons that lead women to leave engineering at higher rates than men, but the conclusion based on Panel A that the most important reason is pay and promotion is reinforced by the fact that the largest coefficient in Panel B is for pay and promotion (column 2). For science, the difference-in-differences effect is statistically significant for family-related reasons (column 1), but is insignificant for all other reasons.

I approach the importance of family from another angle, by using information on the presence of children in the household, despite the likelihood that having children and leaving a field are often decided jointly. In Table 7 column 1, I reproduce the results of Table 5 column 3 for the probability of having a job unrelated to field of study. In column 2, I add controls for having a child in the household and its interactions with female, science and engineering. Having a child is associated with a 2.7 percentage point lower probability of a job unrelated to field of study, but the unreported coefficients on the interaction terms are statistically insignificant, while the addition of the child covariates does not change the difference-in-differences coefficients compared to column 1. In column 3, I control for the triple interactions of female and child with science and engineering. Their coefficients hint that while there is a particular difficulty for women combining children and career in engineering, it is not the case in science, the reverse of 
the results based on the reason given for leaving the field of study. Women trained as engineers have a 3.7 percentage point more positive association between having a child and having an unrelated job than other workers. The coefficient on the interaction of female and engineering now represents the effect for childless women: although the coefficient of 3.8 percentage points is one third smaller than the column 1 value for all women, it remains sizeable, indicating that most of the excess female exits from engineering are not attributable to children.

Women's apparent difficulty in combining engineering and children appears to have disappeared for more recent cohorts and in more recent years, however, the only effect in the paper to have a clear evolution of this type. I therefore present the results for 2003, in columns 4 and 5, and for respondents who received their degree in 1980 or later, in column 6. The 2003 coefficient on the triple interaction of child, engineering and female is zero or negative, statistically insignificant, and statistically significantly smaller than the 1993 coefficient. Consistent with this, the addition of the triple interaction to the 2003 regression has no effect on the estimated excess exits of women from engineering (as shown by comparing the table's results with unreported results). The coefficient for more recent cohorts is less than half the size of the pooled column 3 coefficient, and statistically insignificant. The distinction between the two 2003 regressions is that the regression of column 5 controls for job preferences, which cuts the female coefficient in half, but does not affect other coefficients.

It is possible that women report dissatisfaction with pay and promotion opportunities in engineering because they are more likely to be sidelined upon returning from a career break than in other fields, due to the rapid advancement of technology. Preston (2004) shows that among former scientists and engineers who re-enter science and engineering, those re-entering the fastest-evolving fields have the lowest wages compared to those who never left science and engineering. If this explanation were correct, pay and promotion dissatisfaction should be equally salient in science, which is not the case. Nevertheless, I investigate this possibility further, using the 1993 data which include actual experience. I define a dummy to represent a career break of more than five years, using actual experience 
and year of highest degree. Naturally, a career break could be the outcome of leaving a field rather than the cause, but as for children, the correlations could prove informative. I take the pay and promotion specification of Table 6 Panel A, column 2, and add a quadratic in actual experience, the career break dummy, and its interaction with science and with engineering. The addition of the controls does not affect the difference-indifferences coefficients, although the coefficient on the career break dummy is positive and significant, as is the coefficient on its interaction with science (these results are not reported). This casts doubt on the career break explanation for female pay and promotion concerns in engineering.

\subsection{Do science and engineering differ due to their high share of men?}

Rather than posing unique problems for women, science (in terms of compatibility with

family) and engineering (in terms of pay and promotion causing difficulties) may reflect problems that grow as the male share of the field increases. Figure 2 gives a sense of the potential importance of the male share in the field of study of the highest degree. For each of the 143 detailed fields, I plot the excess female exit rate against the share male. The relation is strongly positive, and the $R^{2}$ of the regression line, weighted by the number of workers trained in the field, is fully 0.26 . The slope of 0.12 indicates that a 10 percentage point increase in the male share increases the gender gap in the exit rate by 1.2 percentage points. The positive relation holds within both science and non-science and engineering, though not within engineering. Few non-science and engineering fields are as male-dominated as the engineering fields, and most exceptions are technology fields.

I investigate this further by extending the individual-level regressions of Tables 5 and 6. In the baseline in column 1 of Table 8, there is a 5.1 percentage point excess female exit rate from engineering. In column 2, I control for the male share in the field of study and its interaction with a female dummy: this causes the excess exit rates for both science and engineering to flip from positive to statistically significantly negative: 
engineering loses 4.9 percentage points fewer women than one would expect. Men are much less likely to leave male-dominated fields (a 10 percentage point increase in the male share reduces the male exit rate by 1.9 percentage points), while women's exit rates are positively affected by the male share (bottom row), which means that there are excess female exits from male-dominated fields generally. Once this is controlled for, the relative female exit rates from science and engineering look favorable compared to other fields.

I investigate whether the share of male workers in a field may be proxying for other underlying characteristics of jobs in the field, though a full treatment is beyond the scope of the paper due to limitations of the cross-section data, and I do not report the results. The Table 8 results are not affected by controlling for average weekly work hours (or share of workers with hours over 45 or 50) of stayers in the field and its interaction with a female dummy (both coefficients are insignificant), nor by the addition of average wages of stayers and its interaction with female (the interaction with female has an insignificant coefficient). Controlling for hierarchy in the career path with the share of stayers who are supervisors and who are supervisors of supervisors (and their interactions with a female dummy) does not explain the excess female exit rate either: male fields have many supervisors or supervisors, but men and women are equally encouraged to remain in more hierarchical fields.

In Table 8 columns 3-6, I relate the male share covariates to the main reason for leaving the field. Columns 3 and 4 show that the male share covariates have only small effects on leaving the field for family-related reasons, and that the excess female exit rate from science is therefore little affected by their inclusion (1.2 percentage points rather than 1.5 percentage points). However, in columns 5-6 I show that due to the large effects of the male share covariates on leaving a field for pay and promotion reasons, their inclusion fully explains the 3.1 percentage point excess exit rate from engineering for this reason. Women's concerns about pay and promotion are therefore not an engineering-specific issue, but an issue general to male-dominated fields. For the unreported other possible reasons, there are no excess exits before male share covariates are included, and the signs flip to negative and significant, though small, after their inclusion (see Hunt 2010). The 
results suggest that one should not look for explanations connected with the nature of scientific and engineering work (with the exception of science and family compatibility), but for explanations of female retention difficulties that become more severe as the share of men in the work force increases, and affect women's pay and promotion.

\section{Conclusion}

My paper reveals that there are excess female exits from engineering, though not from science, and that the excess exits are to jobs in an unrelated field, rather than to nonemployment. Neither worker characteristics nor worker preferences over job attributes, including salary and opportunities for advancement, contribute to explaining the excess female exits from engineering, and I find no differential impact of career breaks for engineers, nor a differential impact of children for women trained as engineers. However, $60 \%$ of the excess exits are attributable to concerns of women engineers regarding pay and promotion opportunities. The factors stressed in the literature, such as family considerations and work conditions, play little or no role. Family considerations are a negative factor for women trained as scientists, however, even though they are counterbalanced by positive factors.

The results would appear to point to problems for women specific to the engineering profession. However, I show that the excess exits of women trained as engineers, as well as their excess exits for pay and promotion reasons, are no larger than would be expected given the share of men in the field: the higher the male share, the greater the excess female exits from the field, both in total and for pay and promotion reasons. This suggests that the most useful remedies would tackle women's lack of mentoring and networks as well as possible discrimination by managers and co-workers, and would be applied to all fields with a high share of male workers. The slight excess female exits from science for familyrelated reasons are not accounted for by the share of trained scientists that is male. 


\section{References}

Antecol, Heather and Deborah Cobb-Clark. 2010. "Do Non-Cognitive Skills Help Explain the Occupational Segregration of Young People?". IZA Discussion Paper 5093.

Fouad, Nadya A. and Romila Singh. 2011. "Stemming the Tide: Why Women Leave Engineering", Center for the Study of the Workplace report, University of WisconsinMilwaukee.

Frehill, Lisa M. 2009. "SWE Retention Study and Work/Life Balance". Society of Women Engineers Magazine, Fall, pp. 34-40.

Frehill, Lisa M. 2008. "Why do women leave the engineering work force?". Society of Women Engineers Magazine, Winter, pp. 24-26.

Frehill, Lisa M. 2007. "Are women more or less likely than men to be retained in engineering after college?". Society of Women Engineers Magazine, Fall, pp. 22-25.

Hall, Linley Erin. 2007. Who's Afraid of Marie Curie? The Challenges Facing Women in Science and Technology, Emeryville, C.A.: Seal Press.

Hewlett, Sylvia Ann, Carolyn Buck Luce and Lisa J. Servon. 2008. "The Athena Factor: Reversing the Brain Drain in Science, Engineering, and Technology". Harvard Business Review Research Report 10094.

Hunt, Jennifer. 2011. "Why Don’t Women Patent?" NBER Working Paper 17888.

Hunt, Jennifer. 2010. "Why Do Women Leave Science and Engineering?" NBER Working Paper 15853.

Morgan, Laurie A. 2000. "Is Engineering Hostile to Women? An Analysis of Data from the 1993 National Survey of College Graduates". American Sociological Review, Vol. 65 (2), pp. 316-321.

Preston, Anne. E. 1994. "Why Have All the Women Gone? A Study of Exit of Women from the Science and Engineering Professions". American Economic Review, Vol. 84 pp. 1446-1462.

Preston, Anne E. 2004. Leaving Science: Occupational Exit from Science Careers, New York: Russell Sage Foundation.

Preston, Anne E. 2006. "Women Leaving Science". Haverford College working paper.

Rosser, Sue V. and Mark Zachary Taylor. 2009. "Why Women Leave Science". Technology Review January/February. Available at www.technologyreview.com/article/21859/, accessed 15 April 2009. 
Sonnert, Gerhard and Gerald Holton. 1995. Gender Differences in Science Careers, New Brunswick, N.J.: Rutgers University Press.

Stinebrickner, Todd and Ralph Stinebrickner. 2011. "Math or Science? Using Longitudinal Expectations Data to Examine the Process of Choosing a College Major". University of Western Ontario working paper.

Stephan, Paula E. and Sharon G. Levin. 2005. "Leaving Careers in IT: Gender Differences in Retention". Journal of Technology Transfer, Vol.30 pp.383-396.

Xie, Yu and Kimberlee A. Shauman. 2003. Women in Science, Cambridge, M.A.: Harvard University Press.

Zafar, Basit. 2008. "College Major Choice and the Gender Gap". Federal Reserve Bank of New York working paper. 


\section{Data Appendix}

I use the 1993 and 2003 waves of the National Survey of College Graduates (NSCG), data collected under the auspices of the National Science Foundation. The data may be downloaded at sestat.nsf.gov/datadownload/. The surveys are a stratified random sample of respondents to the 1990 and 2000 census long forms who reported having a bachelor's degree or higher. I drop respondents who live outside the United States or in U.S. territories, or who are aged 65 or older. I include in all samples those who are selfemployed on their principal job. I would like to exclude full-time students, but I cannot identify students in 1993, except those who say they are either working part-time or not working because they are students. I therefore exclude in both years all these students from the analysis of the probability of employment, and the part-time worker students from the analysis of working in the field of study of highest degree. I scale the weights from the 1993 and 2003 surveys so the sum of weights is equal for each year.

I define science as natural science, including mathematics, and excluding social science and health fields. I define engineering to include computer science. Field of study is provided in 30 or 143 categories. To use 142 field dummies as controls seems excessively detailed, but the more aggregate categorization is rather coarse for fields outside science, engineering and social science. For these fields, I therefore examine the finer categorization for my sample of workers, and select the six finer fields studied by more than $2 \%$ of workers. I use these and the 30 aggregate categories to create 36 field of study categories, listed in Appendix Table 1.

I could follow the existing literature by basing exit from a field on occupation rather than job relatedness to highest degree, though I cannot then associate a reason with the field change, and there is not an obvious equivalent to leaving science and engineering for workers trained in other fields. Of workers with a highest degree in science and engineering, who said their current job was unrelated to their field of study, $89 \%$ and $82 \%$ respectively were not working in a science or engineering occupation. 


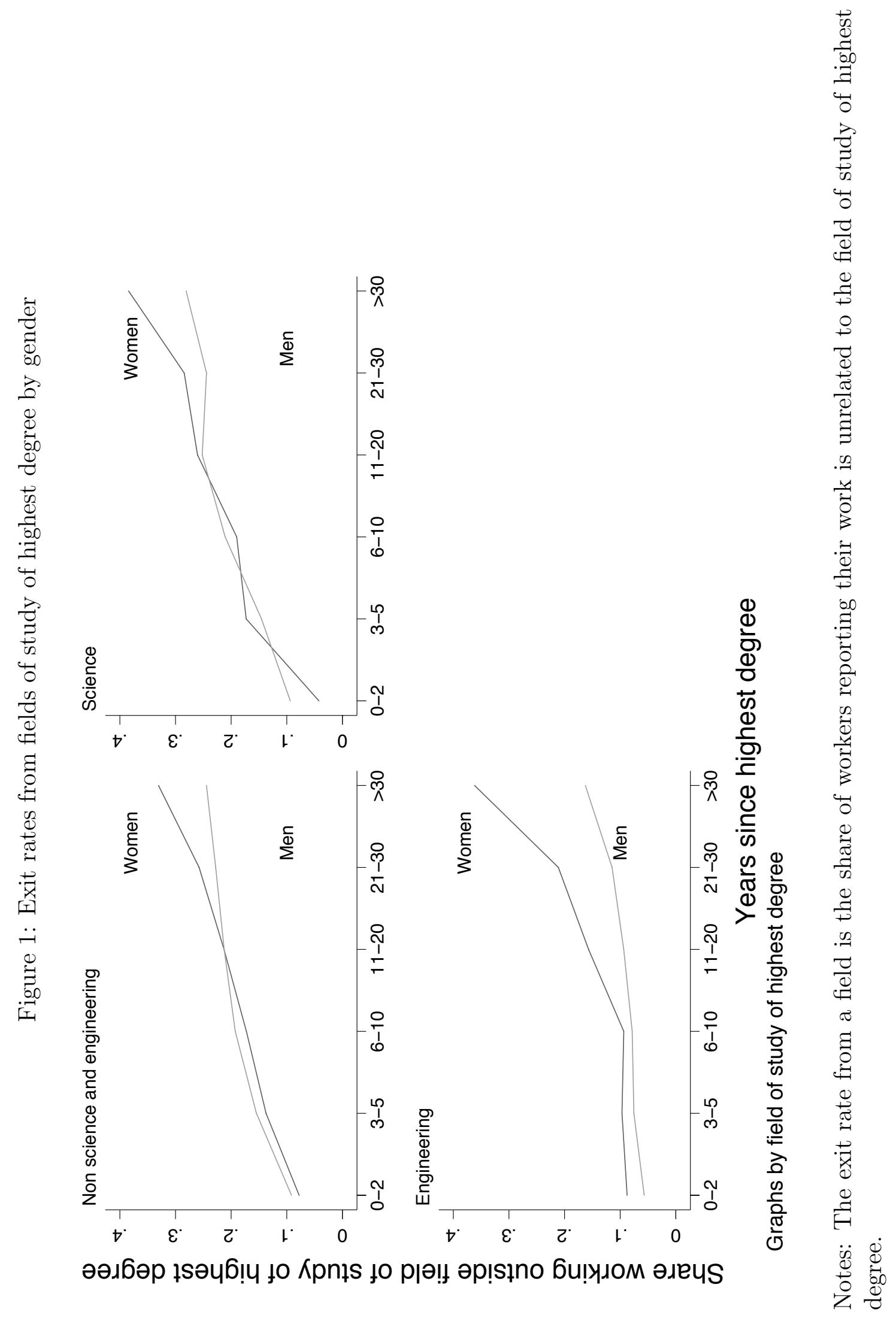




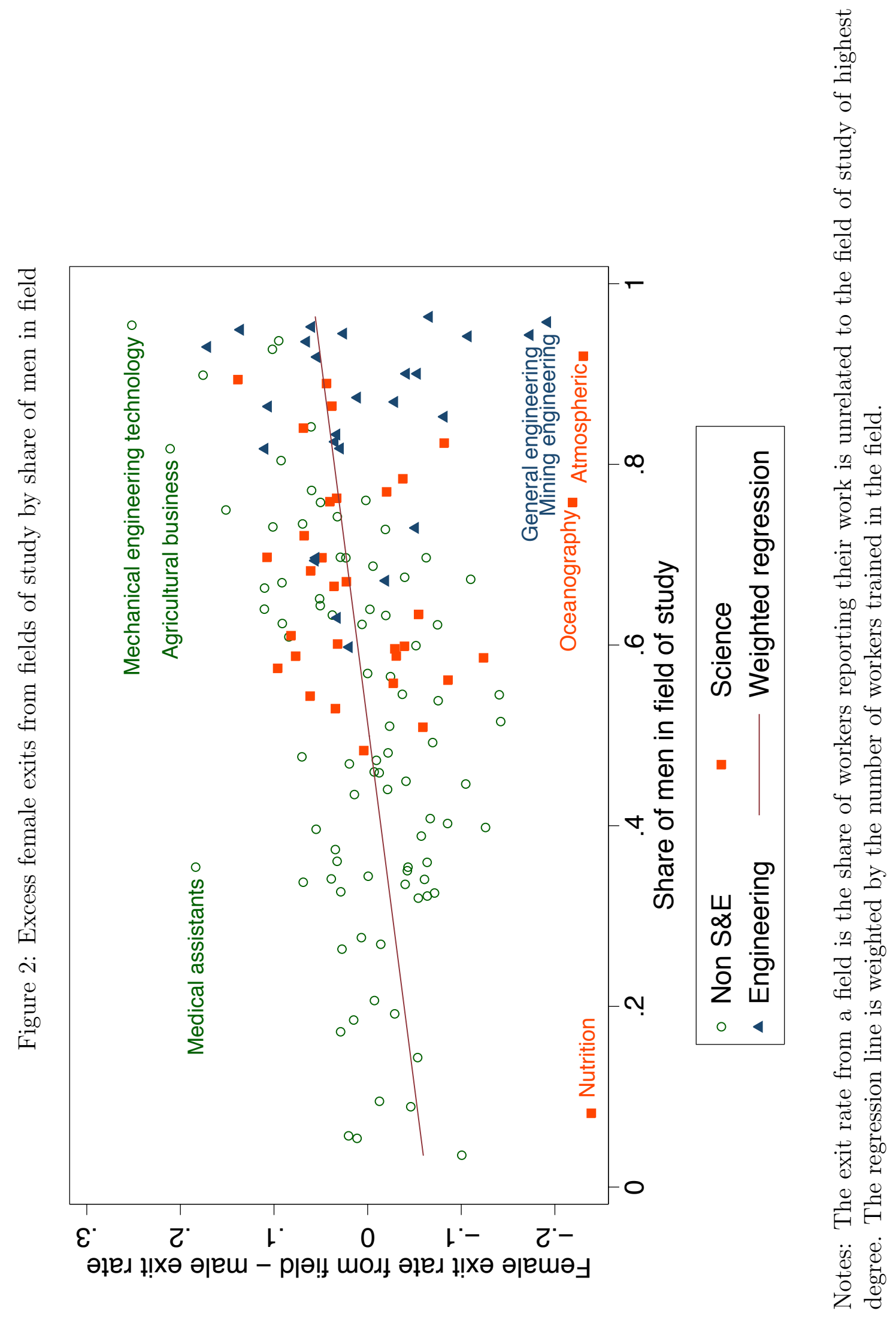


Table 1: Relation Between Job and Highest Degree (\%)

\begin{tabular}{lccc}
\hline & Male workers & Female workers & All workers \\
\hline Closely related & 52.5 & 58.3 & 55.1 \\
Somewhat related & 28.1 & 21.1 & 25.0 \\
Not related & 19.4 & 20.6 & 19.9 \\
& $100 \%$ & $100 \%$ & \\
\hline Not related; main reason is: & & & 2.5 \\
Family related & 1.2 & 4.1 & 2.1 \\
Work conditions & 1.8 & 2.4 & 5.4 \\
Pay, promotion & 6.5 & 4.1 & 3.1 \\
No job in field & 3.1 & 3.2 & 3.8 \\
Change in career interests & 3.7 & 3.8 & 0.9 \\
Job location & 1.0 & 0.9 & 2.1 \\
Other reason & 2.1 & 2.1 & $19.9 \%$ \\
& $19.4 \%$ & $20.6 \%$ & 5.9 \\
\hline Not related; one reason is: & & & 9.5 \\
Family related & 4.1 & 8.2 & 10.7 \\
Work conditions & 8.3 & 10.9 & 6.5 \\
Pay, promotion & 11.8 & 9.4 & 9.3 \\
No job in field & 6.3 & 6.7 & 8.6 \\
Change in career interests & 9.3 & 9.3 & 2.7 \\
Job location & 8.0 & 9.3 & 2.7 \\
Other reason & 2.7 & & \\
\hline
\end{tabular}

Notes: Shares are weighted with survey weights. The sample size is 197,686. Respondents were asked "... to what extent was your work on your principal job related to your highest degree? Was it...". Respondents who answered "not related", were asked "Did these factors influence your decision to work in an area outside of your HIGHEST degree field?". In 2003, the working conditions option specifies "e.g. hours, equipment, working environment" and the family-related option specifies "e.g. children, spouse's job moved". 
Table 2: Employment Rate by Gender and Field of Highest Degree (\%)

\begin{tabular}{lccc}
\hline & Men & Women & Difference \\
\hline Science & 92.4 & 81.5 & $-10.9^{* *}$ \\
Engineering & 92.6 & 84.0 & $-8.7^{* *}$ \\
Other field of study & 92.6 & 81.4 & $-11.2^{* *}$ \\
Difference: & -- & -- & 0.3 \\
science versus other & & & $(0.7)$ \\
Difference: & -- & -- & $2.5^{* *}$ \\
engineering versus other & & & $(0.8)$ \\
\hline
\end{tabular}

Note: Weighted mean of dummy for whether working in survey week. Computer science is included in engineering, mathematics in science. Fields refer to the field of study of the highest degree. The sample size is 222,853 . Standard errors in parentheses. ${ }^{* *}$ indicates significance at the $5 \%$ level, ${ }^{*}$ at the $10 \%$ level. 
Table 3: Workers in Job Unrelated to Highest Degree, by Gender and Field of Highest Degree (\%)

\begin{tabular}{lccc}
\hline & Male workers & Female workers & Difference \\
\hline Science & 23.4 & 24.4 & 1.0 \\
Engineering & 9.8 & 12.9 & $3.1^{* *}$ \\
Other field of study & 20.7 & 20.6 & -0.1 \\
Difference: & -- & -- & 1.1 \\
science versus other & & & $(1.0)$ \\
Difference: & -- & -- & $3.2^{* *}$ \\
engineering versus other & & & $(0.8)$ \\
\hline
\end{tabular}

Note: Weighted mean of dummy for whether job is unrelated to highest degree. Computer science is included in engineering, mathematics in science. Fields refer to the field of study of the highest degree. The sample size is 197,686 . Standard errors in parentheses.

** indicates significance at the $5 \%$ level, ${ }^{*}$ at the $10 \%$ level. 
Table 4: Effect of Field of Study and Gender on Probability of Working

\begin{tabular}{lccc}
\hline & $(1)$ & $(2)$ & $(3)$ \\
\hline Female $\times$ science & 0.003 & -0.005 & -0.001 \\
& $(0.007)$ & $(0.007)$ & $(0.007)$ \\
Female $\times$ engineering & $0.027^{* *}$ & $0.013^{* *}$ & 0.006 \\
& $(0.008)$ & $(0.008)$ & $(0.008)$ \\
$\mathrm{R}^{2}$ & 0.03 & 0.03 & 0.08 \\
Field of study & 2 & 35 & 35 \\
Other covariates & -- & -- & Yes \\
\hline
\end{tabular}

Note: Dependent variable is a dummy for working in the survey week. Weighted linear probability coefficients with robust standard errors in parentheses. The sample size is 222,853. All regressions include a female dummy, a year dummy and a female $\times 1993$ dummy. Field of study controls in column 1 are dummies for science and engineering. Other covariates are dummies for a master's degree, a doctoral degree or a professional degree, five dummies for years since highest degree, six dummies for age, dummies for black, Hispanic, Asian, and dummies for foreign born. Science and engineering refer to the field of study of the highest degree. ${ }^{* *}$ indicates significance at the $5 \%$ level, ${ }^{*}$ at the $10 \%$ level. 
Table 5: Effect of Field of Study and Gender on Having a Job Unrelated to Highest Degree

\begin{tabular}{lccc}
\hline & $(1)$ & $(2)$ & $(3)$ \\
\hline Female×science & 0.011 & $0.016^{*}$ & 0.005 \\
& $(0.010)$ & $(0.010)$ & $(0.010)$ \\
Female× engineering & $0.033^{* *}$ & $0.057^{* *}$ & $0.058^{* *}$ \\
& $(0.008)$ & $(0.009)$ & $(0.009)$ \\
$\mathrm{R}^{2}$ & 0.01 & 0.07 & 0.10 \\
Field of study dummies & 2 & 35 & 35 \\
Other covariates & -- & -- & Yes \\
\hline
\end{tabular}

Note: Dependent variable is a dummy for working in a job unrelated to the highest degree. Weighted linear probability coefficients with robust standard errors in parentheses. The sample size is 197,686. Regressions include a female dummy, a year dummy and a female $\times 1993$ dummy. Field of study controls in column 1 are dummies for science and engineering. Other covariates are three education dummies, five dummies for years since highest degree, six dummies for age, dummies for black, Hispanic, Asian, and dummies for foreign born. Science and engineering refer to the field of study of the highest degree.

${ }^{* *}$ indicates significance at the $5 \%$ level, ${ }^{*}$ at the $10 \%$ level. 
Table 6: Effect of Field of Study and Gender on Job Unrelated to Highest Degree for Various Reasons

\begin{tabular}{|c|c|c|c|c|c|c|c|}
\hline & $\begin{array}{c}\text { Family- } \\
\text { related } \\
(1)\end{array}$ & $\begin{array}{c}\text { Pay, } \\
\text { promotion } \\
(2)\end{array}$ & $\begin{array}{c}\text { Working } \\
\text { conditions } \\
(3)\end{array}$ & $\begin{array}{l}\text { No job } \\
\text { in field } \\
(4)\end{array}$ & $\begin{array}{c}\text { Change in } \\
\text { interests } \\
(5)\end{array}$ & $\begin{array}{c}\text { Job } \\
\text { location } \\
(6)\end{array}$ & $\begin{array}{c}\text { Other } \\
\text { reason } \\
(7) \\
\end{array}$ \\
\hline \multicolumn{8}{|l|}{ A. Main reason } \\
\hline Female $\times$ science & $\begin{array}{l}0.013^{* *} \\
(0.005)\end{array}$ & $\begin{array}{c}0.002 \\
(0.006)\end{array}$ & $\begin{array}{l}-0.003 \\
(0.003)\end{array}$ & $\begin{array}{l}-0.006 \\
(0.005)\end{array}$ & $\begin{array}{l}-0.002 \\
(0.005)\end{array}$ & $\begin{array}{c}0.000 \\
(0.003)\end{array}$ & $\begin{array}{c}0.001 \\
(0.003)\end{array}$ \\
\hline Female $\times$ engineering & $\begin{array}{c}0.003 \\
(0.004)\end{array}$ & $\begin{array}{l}0.036^{* *} \\
(0.004)\end{array}$ & $\begin{array}{c}0.003 \\
(0.003)\end{array}$ & $\begin{array}{c}0.004 \\
(0.004)\end{array}$ & $\begin{array}{c}0.006 \\
(0.004)\end{array}$ & $\begin{array}{c}0.000 \\
(0.002)\end{array}$ & $\begin{array}{l}0.006^{* *} \\
(0.003)\end{array}$ \\
\hline $\mathrm{R}^{2}$ & 0.02 & 0.04 & 0.01 & 0.01 & 0.02 & 0.01 & 0.01 \\
\hline \multicolumn{8}{|l|}{ B. Any reason } \\
\hline Female $\times$ science & $\begin{array}{l}0.018^{* *} \\
(0.007)\end{array}$ & $\begin{array}{l}-0.007 \\
(0.008)\end{array}$ & $\begin{array}{c}0.012 \\
(0.008)\end{array}$ & $\begin{array}{l}-0.004 \\
(0.007)\end{array}$ & $\begin{array}{l}-0.003 \\
(0.007)\end{array}$ & $\begin{array}{c}0.000 \\
(0.008)\end{array}$ & $\begin{array}{c}0.001 \\
(0.004)\end{array}$ \\
\hline Female $\times$ engineering & $\begin{array}{c}0.008 \\
(0.006)\end{array}$ & $\begin{array}{l}0.043^{* *} \\
(0.006)\end{array}$ & $\begin{array}{l}0.013^{* *} \\
(0.006)\end{array}$ & $\begin{array}{l}0.014^{* *} \\
(0.006)\end{array}$ & $\begin{array}{l}0.028^{* *} \\
(0.006)\end{array}$ & $\begin{array}{l}0.015^{* *} \\
(0.006)\end{array}$ & $\begin{array}{l}0.008^{* *} \\
(0.004)\end{array}$ \\
\hline $\mathrm{R}^{2}$ & 0.04 & 0.07 & 0.05 & 0.03 & 0.04 & 0.05 & 0.01 \\
\hline
\end{tabular}

Note: Dependent variable is a dummy for working in a job unrelated to the highest degree. Weighted linear probability coefficients with robust standard errors in parentheses. The sample size is 197,686. All regressions include a female dummy, a year dummy, a female $\times 1993$ dummy, 35 field of highest degree dummies, three education dummies, five dummies for years since highest degree, six dummies for age, dummies for black, Hispanic, Asian, and dummies for foreign born. Science and engineering refer to the field of study of the highest degree.

${ }^{* *}$ indicates significance at the $5 \%$ level, ${ }^{*}$ at the $10 \%$ level. 
Table 7: Effect of Children on Having a Job Unrelated to the Highest Degree

\begin{tabular}{|c|c|c|c|c|c|c|}
\hline & (1) & $\begin{array}{c}\text { (2) } \\
\text { Full sample }\end{array}$ & (3) & $\begin{array}{l}(4) \\
200\end{array}$ & aly & $\begin{array}{c}\text { (6) } \\
\text { Highest } \\
\text { degree } 1980 \\
\text { or later } \\
\end{array}$ \\
\hline Female $\times$ science & $\begin{array}{c}0.005 \\
(0.010)\end{array}$ & $\begin{array}{c}0.006 \\
(0.010)\end{array}$ & $\begin{array}{l}-0.004 \\
(0.014)\end{array}$ & $\begin{array}{c}0.005 \\
(0.024)\end{array}$ & $\begin{array}{c}0.008 \\
(0.023)\end{array}$ & $\begin{array}{l}-0.018 \\
(0.018)\end{array}$ \\
\hline Female $\times$ engineering & $\begin{array}{l}0.058^{* *} \\
(0.009)\end{array}$ & $\begin{array}{l}0.058^{* *} \\
(0.009)\end{array}$ & $\begin{array}{l}0.038^{* *} \\
(0.012)\end{array}$ & $\begin{array}{l}0.076^{* *} \\
(0.021)\end{array}$ & $\begin{array}{l}0.073^{* *} \\
(0.021)\end{array}$ & $\begin{array}{l}0.039^{* *} \\
(0.013)\end{array}$ \\
\hline Female & $\begin{array}{c}-0.020^{* *} \\
(0.005)\end{array}$ & $\begin{array}{l}-0.024^{* *} \\
(0.005)\end{array}$ & $\begin{array}{l}-0.023^{* *} \\
(0.005)\end{array}$ & $\begin{array}{l}-0.030^{* *} \\
(0.007)\end{array}$ & $\begin{array}{l}-0.016^{* *} \\
(0.007)\end{array}$ & $\begin{array}{l}-0.022^{* *} \\
(0.007)\end{array}$ \\
\hline Child in household & -- & $\begin{array}{l}-0.027^{* *} \\
(0.004)\end{array}$ & $\begin{array}{l}-0.025^{* *} \\
(0.004)\end{array}$ & $\begin{array}{l}-0.027^{* *} \\
(0.007)\end{array}$ & $\begin{array}{l}-0.024^{* *} \\
(0.007)\end{array}$ & $\begin{array}{l}-0.024^{* *} \\
(0.005)\end{array}$ \\
\hline Child $\times$ science $\times$ female & -- & -- & $\begin{array}{c}0.018 \\
(0.019)\end{array}$ & $\begin{array}{l}-0.001 \\
(0.032)\end{array}$ & $\begin{array}{l}-0.000 \\
(0.031)\end{array}$ & $\begin{array}{c}0.009 \\
(0.024)\end{array}$ \\
\hline Child $\times$ engineering $\times$ female & -- & -- & $\begin{array}{l}0.037^{* *} \\
(0.017)\end{array}$ & $\begin{array}{l}-0.000 \\
(0.027)\end{array}$ & $\begin{array}{l}-0.008 \\
(0.028)\end{array}$ & $\begin{array}{c}0.015 \\
(0.018)\end{array}$ \\
\hline $\begin{array}{l}\text { Child } \times \text { female, } \\
\text { child } \times \text { science } \\
\text { child } \times \text { engineering }\end{array}$ & -- & Yes & Yes & Yes & Yes & Yes \\
\hline $\mathrm{R}^{2}$ & 0.10 & 0.10 & 0.10 & 0.10 & 0.12 & 0.10 \\
\hline Job preferences & -- & -- & -- & -- & Yes & -- \\
\hline Observations & \multicolumn{3}{|c|}{197,686} & \multicolumn{2}{|c|}{79,213} & 117,016 \\
\hline
\end{tabular}

Notes: Dependent variable is a dummy for working in a job unrelated to the highest degree (columns 1-3) and for working in a job closely related to the highest degree (columns 4-6). Weighted linear probability coefficients with robust standard errors in parentheses. Columns 1-3 and 6 include a year dummy and a female $\times 1993$ dummy. All regressions include 35 field of study dummies, three education dummies, five dummies for years since highest degree, six dummies for age, dummies for black, Hispanic, Asian, and dummies for foreign born. Science and engineering refer to the field of study of the highest degree. ${ }^{* *}$ indicates significance at the $5 \%$ level, ${ }^{*}$ at the $10 \%$ level. 
Table 8: Effect of Male Share in Field of Study on Having a Job Unrelated to Highest Degree

\begin{tabular}{|c|c|c|c|c|c|c|}
\hline & \multicolumn{2}{|c|}{ All reasons } & \multicolumn{2}{|c|}{ Family-related } & \multicolumn{2}{|c|}{ Pay, promotion } \\
\hline & $(1)$ & (2) & (3) & (4) & (5) & (6) \\
\hline Female $\times$ science & $\begin{array}{c}0.009 \\
(0.022)\end{array}$ & $\begin{array}{l}-0.031^{* *} \\
(0.013)\end{array}$ & $\begin{array}{l}0.015^{* *} \\
(0.005)\end{array}$ & $\begin{array}{l}0.012^{* *} \\
(0.005)\end{array}$ & $\begin{array}{c}0.003 \\
(0.011)\end{array}$ & $\begin{array}{l}-0.010 \\
(0.008)\end{array}$ \\
\hline Female $\times$ engineering & $\begin{array}{l}0.051^{* *} \\
(0.021)\end{array}$ & $\begin{array}{l}-0.049^{* *} \\
(0.019)\end{array}$ & $\begin{array}{c}0.003 \\
(0.005)\end{array}$ & $\begin{array}{l}-0.004 \\
(0.006)\end{array}$ & $\begin{array}{l}0.031^{* *} \\
(0.008)\end{array}$ & $\begin{array}{l}-0.006 \\
(0.007)\end{array}$ \\
\hline Share male in study field & -- & $\begin{array}{l}-0.187^{* *} \\
(0.062)\end{array}$ & -- & $\begin{array}{l}-0.012^{* *} \\
(0.006)\end{array}$ & -- & $\begin{array}{l}-0.093^{* *} \\
(0.024)\end{array}$ \\
\hline $\begin{array}{l}\text { Share male in study field } \\
\times \text { female }\end{array}$ & -- & $\begin{array}{l}0.319^{* *} \\
(0.055)\end{array}$ & -- & $\begin{array}{l}0.022^{*} \\
(0.012)\end{array}$ & -- & $\begin{array}{l}0.123^{* *} \\
(0.016)\end{array}$ \\
\hline $\mathrm{R}^{2}$ & 0.06 & 0.06 & 0.02 & 0.02 & 0.02 & 0.02 \\
\hline $\begin{array}{l}\text { Share male in field }+ \\
\text { share male } \times \text { female }\end{array}$ & -- & $\begin{array}{l}0.132^{*} \\
(0.079)\end{array}$ & -- & $\begin{array}{c}0.009 \\
(0.013)\end{array}$ & -- & $\begin{array}{c}0.031 \\
(0.022)\end{array}$ \\
\hline
\end{tabular}

Note: Dependent variable is a dummy for working in a job unrelated to the highest degree. Weighted linear probability coefficients with in parentheses standard errors clustered by detailed field of study (143). The sample size is 197,686. Regressions include controls for female, highest degree in science and highest degree in engineering, a year dummy, a female $\times 1993$ dummy, three education dummies, five dummies for years since highest degree, six dummies for age, dummies for black, Hispanic, Asian, and dummies for foreign born. Science and engineering refer to the field of study of the highest degree. The reasons are the main reason given for having an unrelated job.

${ }^{* *}$ indicates significance at the $5 \%$ level, ${ }^{*}$ at the $10 \%$ level. 
Appendix Table 1: Fields of Study of Highest Degree, by Gender (\%)

\begin{tabular}{|c|c|c|c|c|c|}
\hline & $\begin{array}{c}\text { Male } \\
\text { workers }\end{array}$ & $\begin{array}{c}\text { Female } \\
\text { workers }\end{array}$ & $\begin{array}{c}\text { All } \\
\text { workers }\end{array}$ & $\begin{array}{l}\text { Job not } \\
\text { related }\end{array}$ & $\begin{array}{c}\text { Job closely } \\
\text { related }\end{array}$ \\
\hline \multicolumn{6}{|l|}{ A. Science } \\
\hline Computer and information sciences & 2.8 & 1.5 & 2.3 & 7.6 & 72.2 \\
\hline Mathematics and statistics & 1.9 & 1.3 & 1.6 & 20.9 & 40.7 \\
\hline Agricultural and food sciences & 1.0 & 0.5 & 0.8 & 23.8 & 46.2 \\
\hline Biological sciences & 3.1 & 3.0 & 3.1 & 26.2 & 50.3 \\
\hline Environmental life sciences & 0.5 & 0.2 & 0.4 & 29.5 & 44.0 \\
\hline Chemistry, except biochemistry & 1.3 & 0.6 & 1.0 & 19.6 & 54.8 \\
\hline Earth, atmospheric and ocean sciences & 0.8 & 0.2 & 0.5 & 26.9 & 47.5 \\
\hline Physics and astronomy & 0.8 & 0.1 & 0.5 & 20.0 & 43.3 \\
\hline Other physical sciences & 0.2 & 0.2 & 0.2 & 24.0 & 45.0 \\
\hline \multicolumn{6}{|l|}{ B. Engineering } \\
\hline Aerospace, aeronautical, astronautical & 0.5 & 0.0 & 0.3 & 16.5 & 51.8 \\
\hline Chemical & 0.7 & 0.2 & 0.5 & 11.5 & 50.8 \\
\hline Civil and architectural & 1.9 & 0.2 & 1.2 & 8.7 & 67.2 \\
\hline Electrical and computer & 3.6 & 0.4 & 2.1 & 9.3 & 60.4 \\
\hline Industrial & 0.6 & 0.1 & 0.4 & 17.7 & 40.7 \\
\hline Mechanical & 2.4 & 0.2 & 1.4 & 10.8 & 51.3 \\
\hline Other engineering & 1.7 & 0.2 & 1.0 & 13.9 & 53.1 \\
\hline \multicolumn{6}{|l|}{ C. Non-science and engineering } \\
\hline Economics & 2.1 & 0.7 & 1.5 & 30.5 & 28.2 \\
\hline Political and related sciences & 2.1 & 1.3 & 1.8 & 46.6 & 21.6 \\
\hline Psychology & 2.7 & 5.1 & 3.8 & 26.1 & 45.7 \\
\hline Sociology and anthropology & 1.4 & 2.4 & 1.9 & 37.3 & 29.8 \\
\hline Other social sciences & 1.1 & 1.1 & 1.1 & 40.5 & 31.4 \\
\hline Medicine & 4.5 & 1.9 & 3.3 & 2.4 & 95.0 \\
\hline Other health & 2.3 & 11.0 & 6.2 & 9.1 & 79.4 \\
\hline Technology and technical fields & 1.9 & 0.3 & 1.2 & 13.9 & 51.2 \\
\hline Other science and engineering-related & 0.6 & 0.2 & 0.4 & 15.4 & 65.1 \\
\hline Social service and related & 2.9 & 3.4 & 3.1 & 20.1 & 64.1 \\
\hline Sales and marketing & 3.3 & 2.1 & 2.8 & 17.0 & 38.6 \\
\hline Art and humanities & 7.5 & 11.4 & 9.2 & 39.1 & 37.8 \\
\hline Accounting & 5.3 & 3.7 & 4.6 & 10.9 & 67.2 \\
\hline Business administration, management & 10.7 & 5.6 & 8.4 & 15.5 & 41.6 \\
\hline Other management and administration & 8.0 & 4.0 & 6.2 & 17.9 & 42.7 \\
\hline Elementary teacher education & 1.0 & 11.0 & 5.4 & 18.0 & 72.5 \\
\hline Other (specified) education & 5.7 & 10.5 & 7.9 & 18.5 & 65.0 \\
\hline Other (unspecified) education & 1.9 & 4.7 & 3.1 & 18.8 & 64.3 \\
\hline Law, pre-law, legal studies & 4.7 & 2.5 & 3.7 & 7.6 & 83.0 \\
\hline Other non-science and engineering & 6.6 & 8.1 & 7.3 & 25.8 & 47.2 \\
\hline D. All & 100.0 & 100.0 & 100.0 & 19.9 & 55.1 \\
\hline Observations & 118,192 & 79,494 & & 197,686 & \\
\hline
\end{tabular}

Notes: Shares weighted with survey weights. Column 4 contains the share in the field reporting that their work in the current job is not related to their highest degree of study, column 5 the share reporting their work is closely related to their highest degree of study. 
Appendix Table 2: Means of Covariates by Gender

\begin{tabular}{lccccc}
\hline & $\begin{array}{c}\text { Male } \\
\text { workers } \\
\text { or men }\end{array}$ & $\begin{array}{c}\text { Female } \\
\text { workers } \\
\text { or women }\end{array}$ & $\begin{array}{c}\text { All workers } \\
\text { or all }\end{array}$ & \multicolumn{2}{c}{ All workers or all } \\
& & & 2003 & $\begin{array}{c}\text { Highest degree } \\
1980 \text { or later }\end{array}$ \\
\hline A. Workers & -- & -- & 0.45 & 0.47 & 0.49 \\
Female & 0.62 & 0.65 & 0.63 & 0.63 & 0.60 \\
Bachelor's degree & 0.24 & 0.28 & 0.26 & 0.26 & 0.29 \\
Master's degree (incl. MBA) & 0.05 & 0.02 & 0.04 & 0.04 & 0.04 \\
Doctoral degree & 0.09 & 0.04 & 0.07 & 0.07 & 0.07 \\
Professional degree & 43.5 & 42.0 & 42.8 & 43.8 & 38.0 \\
Age & $(9.5)$ & $(9.4)$ & $(9.4)$ & $(9.7)$ & $(8.0)$ \\
Years since highest degree & 16.7 & 14.8 & 15.9 & 16.6 & 9.8 \\
& $(9.4)$ & $(9.2)$ & $(9.4)$ & $(9.9)$ & $(5.5)$ \\
Black & 0.05 & 0.08 & 0.06 & 0.07 & 0.07 \\
Hispanic & 0.04 & 0.04 & 0.04 & 0.05 & 0.05 \\
Asian & 0.06 & 0.06 & 0.06 & 0.07 & 0.06 \\
Foreign-born & 0.10 & 0.09 & 0.10 & 0.12 & 0.11 \\
Born abroad U.S. citizen & 0.01 & 0.01 & 0.01 & 0.01 & 0.01 \\
Born in U.S. territory & 0.00 & 0.01 & 0.01 & 0.01 & 0.01 \\
Year 2003 & 0.38 & 0.42 & 0.40 & 1 & 0 \\
Child in household & 0.57 & 0.53 & 0.56 & 0.55 & 0.54 \\
Share men in study field & 0.64 & 0.41 & 0.54 & 0.54 & 0.55 \\
Observations & 118,192 & 79,494 & 197,686 & 79,213 & 117,016 \\
\hline B. Workers and non-workers & & & & & 0.86 \\
Working & 0.93 & 0.81 & 0.87 & 0.90 \\
Observations & 127,986 & 94,867 & 222,853 & 90,204 & 128,193 \\
\hline
\end{tabular}

Note: Shares and means weighted with survey weights. Standard deviations in parentheses. 
Appendix Table 3: Workers Attaching Very High Importance to Particular Job Attributes 2003 (\%)

\begin{tabular}{lccc}
\hline & Male workers & Female workers & All workers \\
\hline Salary & 58.4 & 56.5 & 57.5 \\
Benefits & 63.5 & 66.3 & 64.8 \\
Job security & 61.9 & 67.1 & 64.3 \\
Job location & 48.8 & 57.3 & 52.8 \\
Opportunities for & 45.0 & 38.9 & 42.2 \\
advancement & & & \\
Intellectual challenge & 60.5 & 65.4 & 62.8 \\
Level of responsibility & 47.2 & 47.8 & 47.5 \\
Degree of independence & 62.5 & 65.6 & 63.9 \\
Contribution to society & 43.0 & 58.6 & 50.3 \\
Observations & 46,364 & 32,849 & 79,213 \\
\hline
\end{tabular}

Note: Shares weighted with survey weights. The question asked is "When thinking about a job, how important is each of the following factors to you...". The possible answers are very important, somewhat important, somewhat unimportant, not important at all. In the regression, the full set of dummies is controlled for. 